\title{
Evaluation on the biocompatibility, bone cell activity and bone regenerative capacity of chitosan-PLLA bilayer porous membrane
}

\author{
Jun-Beom Park ${ }^{1}$. Sung Heon Nam ${ }^{2} \cdot$ Kyoung-Hwa Kim ${ }^{1} \cdot$ Sang-Chul Lee ${ }^{1} \cdot$ \\ Seung Jin $\mathrm{Lee}^{2} \cdot$ Tae-II Kim $^{1} \cdot$ Yang-Jo Seol $^{1} \cdot$ Yong-Moo Lee $^{1}$ \\ Young $\mathrm{Ku}^{1} \cdot \mathrm{In}-$ Chul Rhyu ${ }^{1} \cdot$ Soo-Boo Han ${ }^{1} \cdot$ Chong-Pyoung Chung ${ }^{1}$ \\ ${ }^{1}$ Department of Periodontology, College of Dentistry, Seoul National University \\ ${ }^{2}$ College of Pharmacy, Ewha Woman's University
}

\section{I . Introduction}

Chitosan is copolymer of $(1 \rightarrow 4)$ glucos amine (2-amino-2-deoxy-D-glucose) and $\mathrm{N}-$ acetyl-D-glucosamine (2-acetamido-2-deoxyD-glucose) which has been reported as a wound healing accelerator ${ }^{1}$. Chitosan is biodegradable cationic pol-ysaccaride that is non-toxic and non-immunogenic ${ }^{2)}$. It is also used as an osteoconductive material which induces or stimulates bone formation ${ }^{3)}$. It stimulates proliferation and differentiation of mesen-chymally derived cells including fibrob-lasts, smooth muscle cells, ligament cells and osteoblasts ${ }^{4}$. The lactic acid is a chiral molecule and it exists in two stereo- isom-eric forms; L-poly(lactic acid) and D-poly(lactic acid). Generally poly(L-lactic acid)(PL-LA) is more frequently employed, since the hydrolysis of PLLA yields $\mathrm{L}(+)-$ lactic acid, which is the naturally occur-ring stereoisomer of lactic acid. The PLLA shows high mechanical strength and toughness and most widely used as synthetic degradable polymers in medicine.

In this study the chitosan mesh was intended for its biocompatible surface of nonimmunogenic properties and PLLA membrane was used for enhancing the mechanical support and excluding the connective tissue ingrowth. The purpose of this study was to investigate the biocompatibility of

\footnotetext{
*This work was supported by the Korean Science and Engineering Federation(KOSEF) through the Intellectual Biointerface Engineering Center at the Seoul National University.

${ }^{*}$ Corresponding author: Chong-Pyoung Chung. Department of Periodontology, College of Dentistry. Seoul National University, 28 Yongon-dong. Chongno-gu, Seoul, 110-749, Korca

Tel:02-2072-2289. Fax:02-744-0051, E-mail:ccpperio (a) snu.ac.kr
} 
the PLLA-chitosan membrane and the biologic effect of this novel membrane as a barrier membrane in bone regeneration.

\section{Materials and Methods}

\section{Materials}

Chitosan was purchased from Tae-Hun Bio(Kyungbook, Korea). PLLA(Mw 370,000) was obtained from Purac Bio-chem BV(Gorinchem. Holland). PLLA dissolved in chloroform gave an intrinsic viscosity of $6.30 \mathrm{dl} / \mathrm{g}$ at $25^{\circ} \mathrm{C}$. Span 80 was purchased from Showa chemicals(Osaka, Japan). Collagenase, $\beta$ glycerol phosp-hate, L-ascorbic acid were obtained from Sigma-Aldrich(St. Louis, MO, USA). Trypsin-EDTA, fetal bovine serum, a -minimumessential medium were purchased from Gibco(Grand Island, NY, USA). All solvents used were of analytical grade.

\section{Fabrication of chiotosan-PLA mem- branes}

Chitosan fibers were prepared by extruding $4 \%$ chitosan solution in $4 \%$ acetic acid into $\mathrm{pH} 13$ aqueous solution. Chitosan fibrous meshes were fabricated by pressing chitosan fibers. PLLA-met-hylene chlorideethylacetate solution was cast on between the two chitosan fibrous meshes using a doctoring blade, and solvents were evaporated in air at $25^{\circ} \mathrm{C}$ for 24 hours and further dried under vacuum for 24 hours to remove residual solvents.

\section{Preparing the cells}

Osteogenic cell line MC3T3-E1 was used. Cell pellets were resuspended and plated in flasks in $30 \mathrm{ml}$ of a-minimum essential me$\operatorname{dium}(\mathrm{a}-\mathrm{MEM})$ containing $10 \%$ fetal bovine serum(FBS) and 1\% antibiotic-antimycotic solution. The flasks were maintained in a humidified atmos-phere consisting of 95\% air and $5 \% \mathrm{CO}_{2}$ at $37^{\circ} \mathrm{C}$. After 3 days, hematopoietic cells and other unattached cells were removed from the flasks by repeated washing with a-MEM. When confluent, the cells were enzymatically lifted from the flask using $0.25 \%$ trypsin in $4 \mathrm{mM}$ EDTA. The cells were concentrated by centrifugation at $4 \times 10^{3}$ rpm for 7 minutes at $4^{\circ} \mathrm{C}$.

\section{Cell seeding into matrices and in vitro culture}

After centrifuging, the supernatant was suctioned away and resuspended in a known amount of media. Cells were counted with a hemacytometer and diluted to $1 \times 10^{5}$ cells $/ \mathrm{ml}$ in complete a-MEM media containing 15\% FBS, $1 \%$ antibiotic-antimycotic solution, 10 $\mathrm{mM} \mathrm{Na} \beta$-glycerol phosphate, $50 \mathrm{\mu} / \mathrm{ml} \mathrm{L-as}{ }^{-}$ corbic acid, and $10^{-7} \mathrm{M}$ dexamethasone. Prewetted membranes with complete media were placed in 24-well plates. Aliquots of $100 \mu \ell$ of cell suspension were seeded onto the top of the membranes resulting in a seeding density of $10^{4}$ cells/membrane. The seeded membranes were left undisturbed in an incubator for 3 hours to allow the cells to attach. Subsequently, an additional $1 \mathrm{ml}$ of complete media was added to each well. 
Medium was changed every 2 to 3 days.

\section{Cell proliferation}

Cell proliferation was measured at 1.7 and 14 days. At each time point, media were removed from the wells. The membranes were washed gently with Hank's balanced salt solution(HBSS) to remove any unattached cells and remaining media. The adherent cells were released from the substrate by incubation in $300 \mu \ell$ of $0.25 \%$ trypsin in $4 \mathrm{mM}$ EDTA for 10 minutes. After digestion, the membranes were washed with $300 \mu$ of HBSS for collecting retained cells. Cells in tryp$\sin /$ HBSS solution were counted by the hemacytometer. After counting, the cells in the media were centrifuged at $5000 \mathrm{rpm}$ for $10 \mathrm{mi}-$ nutes at $4^{\circ} \mathrm{C}$. The supernatant was suctioned away and the cell pellet was prepared for alkaline phosphatase(ALPase) activity test.

\section{SEM view of cell-membrane com- plexes}

Cultured cell-membrane complexes were prepared for scanning electron microscope (SEM) studies at 1, 7 and 14days. They were incubated at low temperature(in ice) in a fixative of $2.5 \%$ of glutaraldehyde for $20 \mathrm{mi}^{-}$ nutes and then washed in PBS for 10minutes twice. The complexes were then incubated for 20 minutes in a postfixative of $1 \%$ aqueous $\mathrm{OsO}_{4}$ andsubsequently washed with PBS for 10minutes. Samples were dehydrated through ascending ethanol $(70,80,90,95$ and twice in $100 \%$ ), allowed to air dry overnight and shadowed with $20 \mathrm{~nm} \mathrm{Au} / \mathrm{Pd}$.

\section{Measurement of alkaline phospha- tase(ALPase) activity}

Production of ALPase was measured spectroscopically at 1,7 and 14 days. Removed cells from the membranes were homogenized with $200 \mu$ of double distilled water(DDW) and sonicated for 1minute in ice. $50 \mu \ell$ of cell lysate were mixed with $100 \mu \ell$ of $0.1 \mathrm{M}$ glycin-NaOH buffer, $50 \mu$ of $15 \mathrm{mM}$ para-nitrophenol phosphate(PNPP), $50 \mu \ell$ of $0.1 \%$ Tri- $^{-}$ ton $\mathrm{X}-100 /$ saline, and $50 \mu$ of DDW. Aliquots were incubated for 30 minutes at $37^{\circ} \mathrm{C}$. After incubation, each tube was added 1.25 $\mathrm{ml}$ of $0.1 \mathrm{~N} \mathrm{NaOH}$ and placed in ice. The production of paranitrophenol(PNP) in the presence of ALPase activity was measured by monitoring light absorbance at $405 \mathrm{~nm}$. The slope of absorbance versus time plot was used to calculate the ALPase activity.

\section{Detection of mRNA by RT-PCR}

Total RNA was isolated from the samples. $0.7 \mu \ell$ of $14.2 \mathrm{M} \beta$-mercaptoeh-thanol $(\beta-\mathrm{ME})$ was added to $100 \mu \ell$ of of Lysis Buffer for each sample. $100 \mu \ell$ of Lysis Buffer- $\beta-M E$ mixture was addedto each cell sample and was vortexed until homogenized. An equal volume of $70 \%$ ethanol to the cell lysate was added and then mixed thoroughly by vortexing for 5 seconds. This mixture was transferred to a seated RNA-Binding Spin Cup. It was spinned in a microcentrifuge at maximum speed for 1 minute and the filtrate was discarded. DNAase treatment was followed as the manufacturer's instructions. $500 \mu \ell$ of $1 \times$ High-Salt Buffer was added and 
spinned and the filtrate was discarded. Then $600 \mu \ell$ of $1 x$ Low-Salt Wash Buffer was added and spinned and the filtrate was discarded. $300 \mu$ of $1 x$ Low-Salt Wash Buffer was added and spinned for 2 minutes to dry the fiber matrix. Spin cup was transferred to a $1.5 \mathrm{ml}$ collection tube. After adding 30 $\mu l$ of Elution Buffer directly onto the fiber matrix, it was incubated for 2 minutes at room temperature and was spinned again at maximum speed for 1 minute. The purified RNA was obtained in the Elution Buffer in the microcentrifuge tube.

RT-PCR was used to assess transcript expression. cDNA was constructed by using kit. Master Mix containing $2 \mu l$ of $10 \mathrm{x}$ reaction buffer, $4 \mu \ell$ of $2 \mathrm{mM} \mathrm{MgCl}_{2}, 2 \mu \ell$ of deoxynucleotide mix, $2 \mu \ell$ of Oligo-p $[\mathrm{dT}]_{15}$ primer, $1 \mu \ell$ of Rnase inhibitor, and $0.8 \mu \ell$ of AMV reverse transcriptase was mixed in sterile microcentrifuge tube. RNA and sterile water were mixed and was incubated for 15 minutes at $65^{\circ} \mathrm{C}$. Following incubation it was kept in ice for 5minutes. The Master Mix made before was put in the tube and incubated for 10 minutes at $25^{\circ} \mathrm{C}$ and kept for 60 minutes at $42 \mathrm{C}$. Reverse transcriptase was denatured by incubating at $100^{\circ} \mathrm{C}$ for 5 minutes and then cooled down to $5^{\circ} \mathrm{C}$.

PCR of the cDNA products was carried out in a final volume of $20 \mu \ell$ containing of $2 \mu \ell$ of cDNA, 1 ul of $20 \mathrm{pmol} / \mu \ell$ of each of the forward and reverse primers, and $16 \mu \mathrm{l}$ of autoclaved DDW. PCR protocol was 30 cycles of denaturing $\left(94^{\circ} \mathrm{C}, 1\right.$ minute $)$, annealing $\left(52^{\circ} \mathrm{C}, 2\right.$ minutes) and primer extension $\left(72^{\circ} \mathrm{C}, 1 \mathrm{mi}-\right.$ nute), which was controlled by the DNA thermal cycler(Mastercycler Gradient, Eppendorf,
Germany). Primers for glyceraldehyde-3-phosphate dehydrogenase(GAPDH), a house keeping gene used for an internal control, collagen type I(CO), osteopontin(OP), and osteocalcin (OC) were designed from the published $\mathrm{se}^{-}$ quences. GAPDH: for-ward, 5'-CACCATGGAG AAGGCCGGG G-3' reverse. 5'-GACGGACACA 'TTGG GGGTAG-3'. CO: forward, 5'-TCTC CAC TCTTCTAGTTCCT -3' reverse, 5'-TTGG GTCATTTCCACATGC-3'. OP: forward, 5'-AC ACTTTCACTCCAATCGTCC $-3^{\prime}$ reverse, 5'-TG CCCTTTCCGTTGTTGTC C-3'. OC: forward, 5'-TCTGACAAACCT TCATGTCC -5 reverse, $5^{\prime}$-AAATAGTG ATACCGTAGATG $\mathrm{CG}^{-} 3^{5}$.

\section{Animal experiment}

8 male Sprague-Dawley rats were used in animal experiments. The animals with chitosan-PLLA membranes were served as test group and the one without membranes were served as control. Rats were ane-sthetized by intraperiotoneal injection of ketamine (30 $\mathrm{mg} / \mathrm{kg}$ body weight). The surgical site was made in the sagittal plane across the cranium. A full-thickness flap including periostem was reflected, exposing the parietal bone. An $8 \mathrm{~mm}$ diameter critical size calvarial defect was created with saline cooled trephine drill. Extreme care was taken to avoid injury to the brain. After removal of the trephined calvarial bone, chitosan-PLLA membranes were implanted into the defects in test group and nothing was applied on the control group. The periosteum and skin were closed using 5-0 chromic gut and 4-0 silk sutures, respectively. Bone regenerative efficacy of the membranes was examined at 

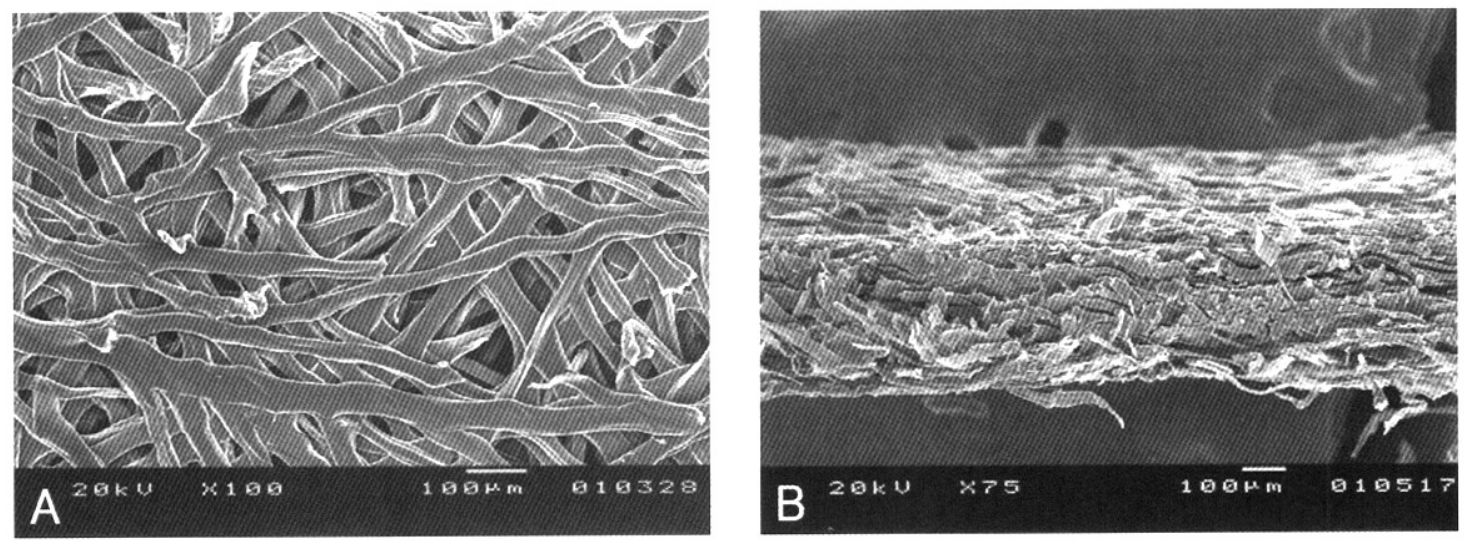

Figure 1. Morphologic appearance of outer surface of the membrane(A) The cross-sectional view of membrane shows the inner PLLA layer(asterik) and outer chitosan layer with distinct interface(arrows).

4 weeks. The histomor-phometric analysis was done at 2 and 4 weeks. The perimeter of newly formed bone was traced and the enclosed area was measured using image analysis software(Image Access).

\section{Statistical analysis}

All measurements were collected from at least in triplicate and expressed as mean standard deviation. The results obtained from the samples at the same time point were analyzed by Mann-Whitney U Test. Values of $p<0.05$ were considered statistically significant.

\section{Results}

\section{The morphology of chitosan-PLLA membranes}

The surface of the membrane revealed a characteristic thin multifibers of chitosan mesh with a slight roughened surface(Figure
1A). The membrane composed of inner PLLA layer and outer chitosan layer observed distinctly in cross-sectioned view(Figure 1B) The pore size of PLLA layer between two chitosan mesh was fallen between 2 to $10 \mu \mathrm{m}$.

\section{Cell proliferation}

To calculatethe increasing rate, the cell numbers of 7 and 14 days were divided by the cell number of day 1 . The cell proliferation rate of day 14 was significantly increased compare to that of day $7(\mathrm{p}<0.05)$ in test group, however, there was no significant difference between two groups at each period(Table 1 and Figure 2).

\section{SEM view of cell-membrane constructs}

At day 1. cells were well attached to the membrane and the cell morphology was round to spindle with elongated cytopl-asmic extension(Figure 3A). At day 7, more cells were attached over the membrane sur- 


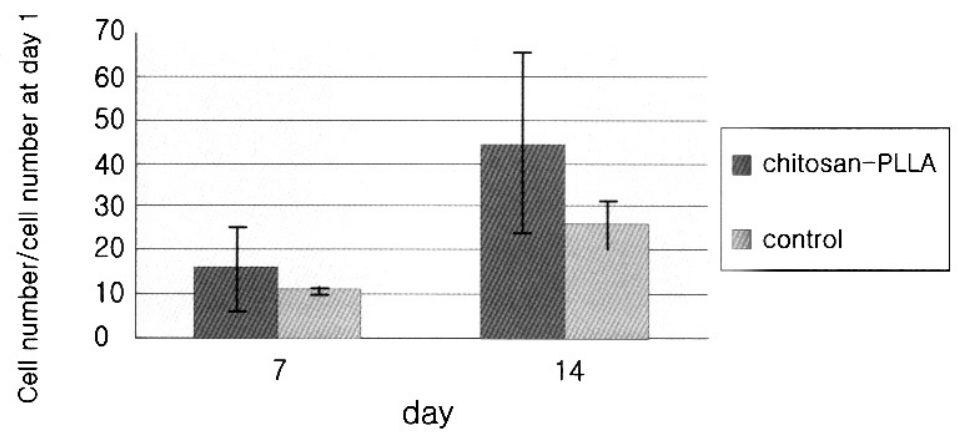

Figure 2. Cell proliferation(cell number/cell number at 1 day)
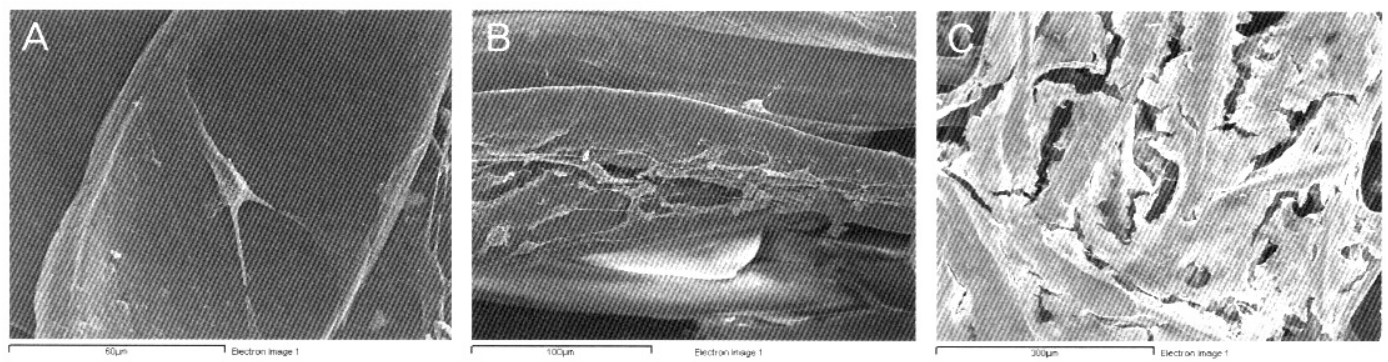

Figure 3. Scanning electron microscopy of chitosan-PLLA membrane.(A) At day 1, cells were well attached to the membrane with elongated cytoplasmic extension(x 1000);(B) At day 7 , more cells were attached over the membrane surface $(x$ 500);(C) At 14 days, membrane was filled with proliferated cells $(\times 200)$.

face(Figure 3B). At day 14, the number of cells was highly increased and the membrane was filled with the proliferated cells(Figure 3C).

\section{Measurement of alkaline phospha- tase(ALPase) activity}

The ALPase activity had an increasing tendency throughout the periods. There was no significant increase after day 7 and 14 compared to day 1 in test group and there was significant difference between the two groups at 7 days $(p<0.05)$ (Table 2 and Figure 4).

Table 1. Cell proliferation(cell number/cell number at 1 day)

\begin{tabular}{c|c|c|}
\hline \multirow{2}{*}{ day } & \multicolumn{2}{|c}{ cell number/cell number at day 1} \\
\cline { 2 - 3 } & Chitosan-PLLA & Control \\
\hline 7 & $15.99 \pm 9.56$ & $11.11 \pm 0.56$ \\
\hline 14 & $44.62 \pm 20.61^{*}$ & $25.81 \pm 6.21$ \\
\hline
\end{tabular}

${ }^{*} \mathrm{P}<0.05$. as compared with day 7 in each group 
Table 2. Alkaline phosphatase activity levels

\begin{tabular}{|c|c|c|}
\hline & Chitosan-PLIA & Control \\
\hline 1 & $0.031 \pm 0.0100$ & $0.033 \pm 0.009$ \\
\hline 7 & $0.027 \pm 0.007$ & $0.033 \pm 0.009 \#$ \\
\hline 14 & $0.043 \pm 0.014$ & $0.049 \pm 0.009^{*}$ \\
\hline
\end{tabular}

${ }^{*} \mathrm{P}<0.05$, as compared with day 1 in each group

\# $\mathrm{P}<0.05$. as compared with chitosan-PLLA

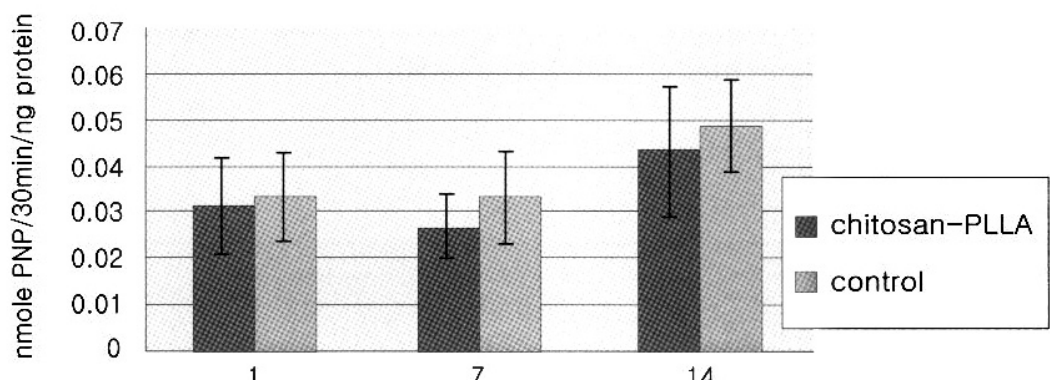

Figure 4. Alkaline phosphatase activity levels
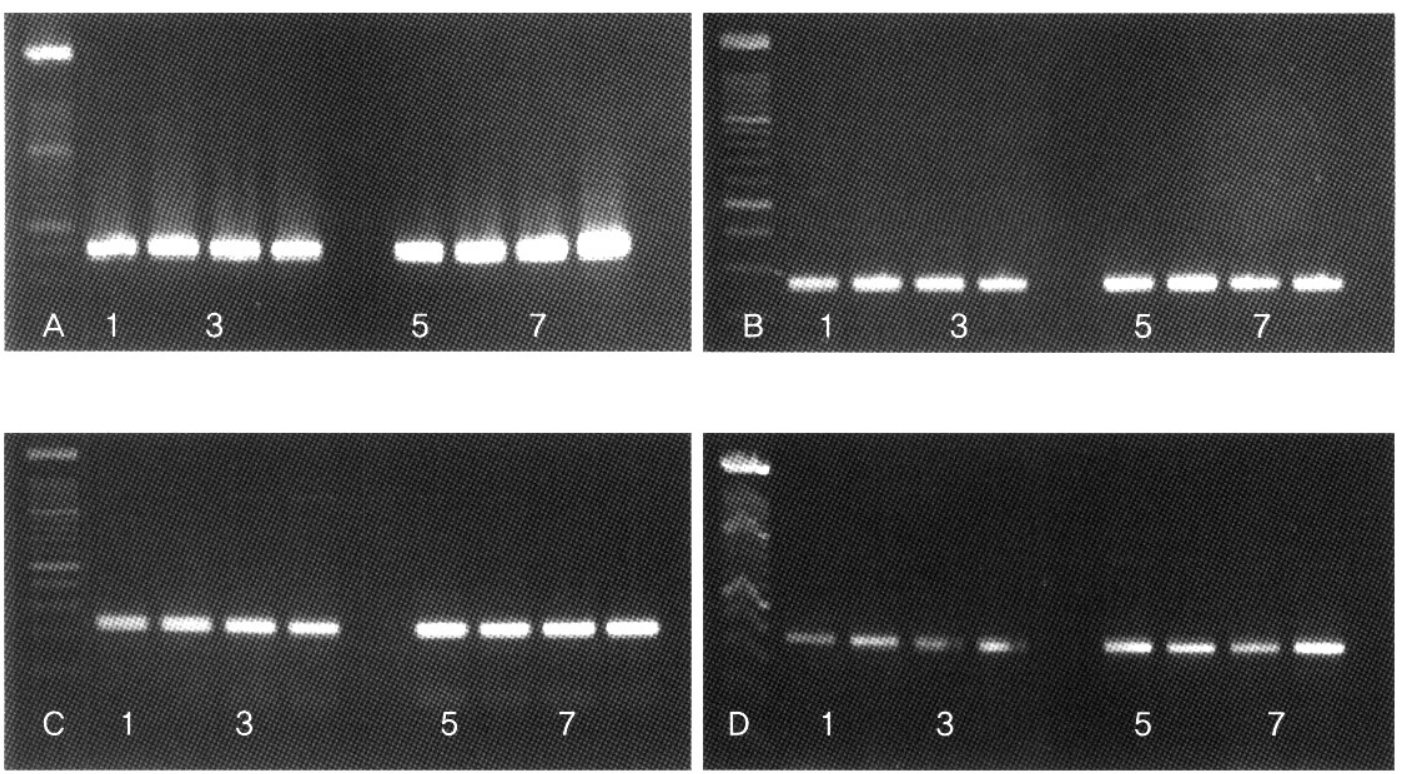

Figure 5. Expression of mRNA in osteoblastic cells.(A)GAPDH(housekeeping gene, $418 \mathrm{bp}$ ) was expressed in all osteoblastic cells.(B,C,D)mRNA for COL(250 bp), OP(239 bp), and OC(198 bp) was expressed in all samples.(1,2,3,4: chitosan-PLLA membrane $1,4,17$ and 14 days $5,6,7,8$ : control $1,4,7$ and 14 days) 

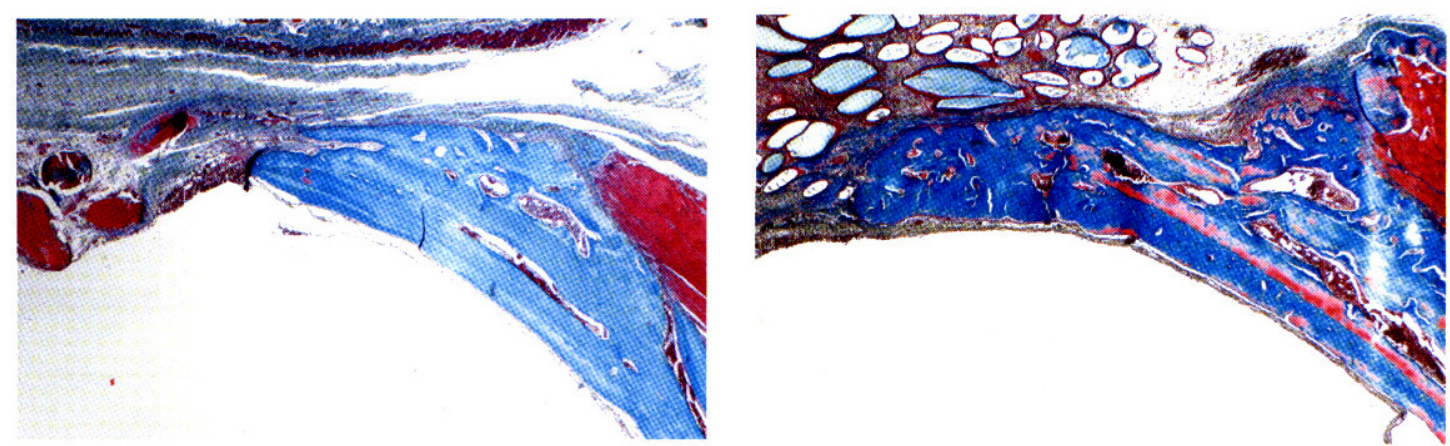

Figure 6. Histologic view in vivo at 4 weeks(A)non-membrane-treated defects were invaded by the thin, loosely organized connective tissue and limited amount of bone repair was observed(arrow).(B)bone regeneration was observed from the periphery toward the center in membrane-treated membrane-treated defects(asterik).

Table 3. Area of new bone in rat calvarial defect

\begin{tabular}{|c|c|c|}
\hline \multirow{2}{*}{ Day } & \multicolumn{2}{|c|}{ area of new bone $\left(\mathrm{mm}^{2}\right)$} \\
\hline & Chitosan Pli.A & Control \\
\hline 7 & $0.127 \pm 0.005^{* *}$ & $0.044 \pm 0.015$ \\
\hline 14 & $0.325 \pm 0.009^{* \star}$ & $0.117 \pm 0.037^{*}$ \\
\hline
\end{tabular}

${ }^{*} \mathrm{P}<0.05$, as compared with day 1 in each group $\# \mathrm{P}<0.05$, as compared with control

\section{Detection of mRNA by RT-PCR}

mRNA for glyceraldehyde-3-phosphate dehydrogenase, collagen type I, osteopontin. and osteocalcin were expressed at 1, 4, 7 and 14 days (Figure 5). The detection of $\mathrm{GA}^{-}$ PDH mRNA in cell extracts served as a pos ${ }^{-}$ itive control for mRNA recovery and reverse transcription. Seeded osteoblasts retained their biochemical phenotype-specific characteristics for bone formation throughout the entire culture period.

\section{Bone regeneration experiment in vivo}

No specimens revealed any evidence of inflammatory reaction and all wounds showed a good healing response. At 4 weeks after surgery, non-membrane-treated wounds were invaded by the thin, loosely organized connective tissue and limited amount of bone repair was observed(Figure 6A). In membranetreated wounds showed bone regeneration in centripedal fashion(Figure 6B). The results of histomorphometric analysis showed that the amount of regenerated bone in the chitosan-PLLA group was significantly( $p<$ 0.05) greater than in the control group in both 7 and 14 days(Table 3 and Figure 7). 


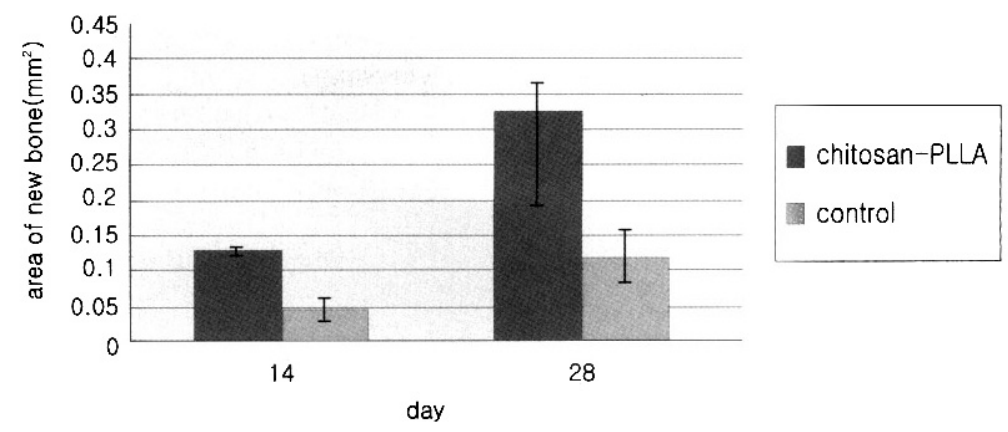

Figure 7. Area of new bone in rat calvarial defect

\section{Discussion}

Chitosan has been reported as a wound healing accelerator ${ }^{13}$. The effect of chitosan on bone wound healing has been examined. Muzzarelli et al. reported improved osseous healing in the defect area ${ }^{6)}$.

The components of culture media were also important in phenotypic expression and $\mathrm{re}^{-}$ tention of osteoblast and matrix mineralization. In this study, the culture media was supplemented with ascorbic acid, $\beta$-glycerophosphate and dexametha-sone. Ascorbic acid probably stimulates the formation and hydroxylation of collagen, permitting sufficient amount of collagenous matrix to bone deposited ${ }^{7)}$. The organic phosphates appear to be necessary for mineralization. In the study by Bellows et al, nodules failed to be mineralized in absence of $\beta$-glycerop-hosphate while nonmineralized nodules formed in the absence of $\beta$-glyceropho-sphate did mineralized when $\beta$-glycer-ophosphate was added ${ }^{8)}$. Glucocorticoids such as dexamethasone, have been shown to cause an initial increase in the activity of a number of osteblast-like cell markers".
The cell number of membranes is lower than that of the control. The membrane had porous structure and all the inoculated cells may not have seeded on the membrane. It might have passed through or overflowed the membrane. To make the day 1 cell number of the membrane similar to that of the control, we could increase the number of seeded cells in the membrane. The surface of polystyrene dish has been known to have good cellular attachment and show rapid cellular confluency in incubation period ${ }^{10}$ and higher increasing rate of the membrane implies good cellular activity.

The initial attachment of osteoblastic cells to the membrane was observed by SEM 1day after incubation. The morphology of the cell was round to spindle with elongated cytoplasmic extension. As time goes on, the cells started to aggregate and the membrane is partially covered with the proliferated cells.

All the RNA samples used in the study showed the single band of GAPDH gene sequence, indicating that the extracted RNA samples were intact and not degraded ${ }^{11)}$. Osteoblasts express various phenotypes such as elevated levels of ALPase activity and par- 
athyroid respons-iveness.

Osteopontin, osteocalcin, and bone sialoprotein may play important roles in cementogenesis, osteoblast differentiation and bone mineralization $^{12)}$. The expression of ALPase activities suggests that seeded bone marrow cells were differentiated into the osteoblasts. During osteoblast differentiation, the increase in ALPase activity occurs earlier than does osteocalcin production. Osteocalin production occurs preferentially in mature osteoblasts $^{13)}$. In present study, chitosan-PLLA membrane retained phenotype-specific characteristics as osteoblast, which implies good cellular adaptability.

\section{Conclusion}

To investigate the biocompatibility of the PLLA-chitosan membrane and to evaluate the biological effect of this novel membrane, osteoblast-like cells were applied to the test membrane. We performed a histologic and tested biochemical approach in vitro. We also evaluated the bone regenerating activity of this membrane using rat calvarial defect in vivo.

1. Seeded cells were well attached to the membrane used. Cell proliferation was significantly increased after 7 and 14 days compared to 1 day ( $p<0.05$ ).

2. SEM view of day 1 showed well attached cell to the membrane. And that of day 7 and day 14 showed increased cell population over times.

3. Expression of collagen type I, osteopo-ntin and osteocalcin mRNA was detected in all samples.
4. At cultured cells, alkaline phosphatase activity was maintained during whole periods.

5. Chitosan-PLLA membrane promoted osseous healing as compared to controls.

These results suggest that the novel chitosan-PLLA porous bilayer membrane has a favorable biologic effect on osteoblast cells. Within the limit of our study, it is concluded that the chitosan-PLLA mem-brane has a good cellular adaptability. Further studies are needed for long-term evaluation of the membrane a barrier membrane in vivo before applying in clinic.

\section{References}

1. Ueno H, Murakami M, Okumura M, Kadosawa T. Uede T, Fujinaga T. Chitosan accelerates the production of osteopontin from polymorphonuclear leukocytes. Biomaterials 2001:22:1667-1673.

2. Jia Z, Shen D, Xu W. Synthesis and antibacterial activities of quaternary ammonium salt of chitosan. Carbohyd-rate $\mathrm{Re}^{-}$ search 2001:333:1-6.

3. Muzzarelli RA. Zucchini C, Ilari P, et al. Osteoconductive properties of met-hylpyrrolidinone chitosan in an animal model Bio- materials 1994:14:925-929.

4. Park YJ, Lee YM, Park SN, Sheen SY, Chung CP. Lee SJ, Platelet derived growth factor releasing chitosan sponge for periodontal bone regeneration. Biomaterials $2001: 21: 153-159$.

5. Qu Q. Perälä-Heape M, Kapanen A, Dahllund J, Salo J, Väänänen HK, Härköne P. 
Estrogen enhances differentiation of $\mathrm{os}^{-}$ teoblasts in mouse bone marrow culture, Bone 1998:22:201-209

6. Muzzarelli RA, Mattioni-Belmonte M, Tiettz C, et al. Stimulatory effect on bone formation exerted by a modified chitosan. Biomaterials 1994;15:1075-1081.

7. Canalis R. Effect of glucocorticoid on type I collagen synthesis, alkaline phosphatase activity, and deoxyribonu-cleic acid content in cultured rat calvaria. Endocrinology 1983:112:931-939.

8. Bellows CG, Aubin JE, Heersche JNM, Antosz ME. Mineralization bone nodules formed in vitro enzymatically released rat calvaria cell populations. Calcif Tissue Int 1986:38:143-154.

9. Canalis R. Effect of glucocorticoid on type I collagen synthesis, alkaline phposphatase activity, and deoxyri-bonucleic acid content in cultured rat calvaria. Endoc rinology 1983:112:931-939.

10. Muzzarelli R, Baldassarre V, Conti F, Ferrera P, Biagini B. Biological activity of chitosan. Ultrastructural study. Biomaterials 1988:9:247-52.

11. Das SJ, Parkar MH, Olsen I. Upregulation of keratinocyte growth factor in $\mathrm{cy}^{-}$ closporin A-induced gingival over-growth. J Periodontol 2001,72:745-752.

12. Bronckers ALJJ, Farach-Carson MC, van Waeren E, Butler WT. Immunoloc-alization of osteopontin, osteocalcin, and den tin sialoprotein during dental root formation and early cementogene-sis in the rat. J Bone Miner Res 1994;9:833-841.

13. Takiguchi T, Kobayashi M, Suzuki R, Yamahuchi A, Isatsu K Nishihara T.
Nagumo M, Hasegawa K. Recombina-nt human bone morphogenetic protein-2 stimulates osteoblast differentiation and suppresses matrixmetalloproteinase -1 prduction in human bone cells isolated from mandibulae. J Periodontal Research 1998: 33:476-485.

14. Lee YM, Park YJ, Lee SJ, Ku Y, Han SB, Choi, SM, Klokkevold PR, Chung CP: Tissue engineered bone formation using chitosan/ tricalcium phosphate sponges. J Periodontol 2000:71:410-417.

15. Lee SY, Seol YJ, Lee YM, Lee JY, Lee SJ, Kim SY, Ku Y, Rhyu IC, Han SB, Choi SM, Chung CP. Yang SM: The effect of platelet derived growth factor-BB loaded chitosan/calcium me-taphosphate on bone regeneration. J Korean Academy of Perio dontology 2001:31:1:1-20.

16. Seol YF, Lee JI, Lee YM, Lim YT, Kim SY, Ku Y, Rhyu IC, Hahm BD, Han SB, Choi SM, Chung CP: Biolog-ical activities of calcium polyphosph-ate. $J$ Korean Academy of Periodon-tology 2000;30:2: 213-228.

17. Palaiologou AA, Yukna RA, Moses R, Lallier TE. Gingival, dermal, and periodontal ligament fibroblasts expr-ess different extracellular matrix recep-tors. JPeriodontol 2001:72:798-807.

18. Lee YM, Park YJ, Lee SJ, Ku Y, Han SB, Klokkevold PR, Chung CP: The bone regenerative effect of platelet-derived growth factor-BB delivered with a chitosan/tricalcium phosphate sponge carrier. J Periodontol 2000:71:418-424.

19. Das SJ, Parkar MH, Olsen I. Upregulation of keratinocyte growth factor in $\mathrm{cy}^{-}$ 
closporin A-induced gingival over-growth. J Periodontol 2001:72:745-752.

20. Zhang $Y$, Zhang M. Microstructural and mrchanical characterization of chitosan scaffolds reinforced by calcium phosphate.
J Non-crystalline solids 2001:159-164.

21. Sofia S, McCarth MB, Gronowicz G, Kaplin DL. Functionalized silk-based biomaterials for bone formation. J Biomed Mater Res 2001:54:139-14 


\title{
Chitosan-PLLA 다증 다공성 차폐막의 생께적합성, 골계포할성도 및 골재생 능력에 관한 연구
}

\author{
박준범 $^{1} \cdot$ 남성헌 $^{2} \cdot$ 김경화 $^{1} \cdot$ 이상철 $^{1} \cdot$ 이승진 ${ }^{2} \cdot$ 김태일 $^{1} \cdot$ 설양조 $^{1} \cdot$

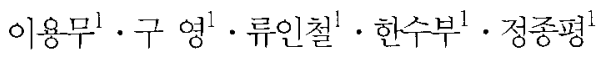 \\ ${ }^{1}$ 서울대학교 치과대학 치주과학교실 \\ ${ }^{2}$ 이화여자대학교 약학대학
}

이 연구의 목적은 새로이 제작된 chitosan-poly(L-lactic acid)(PLLA) 다층 다공성 차폐막의 생체적합성 및 골세포활성도 및 골재생능을 평가하는 것이다.

제작된 차폐막을 24 well에 넣고 clonal osteoblast-like cell line(MC3T3-E1)을 접종한 군을 실험군으 로, 차폐막을 사용하지 않은 대조군으로 하었다. 배양 1 일, 7 일 및 14 일째에 각 well에서 세포수를 측정하였 다. 주사전자현미경을 이용하여 차폐막에 부착된 세포의 형태관찰을 시행하였다. RNA 추출 및 RT-PCR을 실 시한 후, agarose gel상에서 전기영동하여 조골세포 표식자인 collagen type I(COL), osteopontin(OP) 및 osteocalcin(OC) mRNA의 발현을 관찰하였다. 제작된 매트릭스의 생체적합성 및 골재생능을 관찰하기 위하여 백서의 두개골에 직경 $8 \mathrm{~mm}$ 의 원형 결손부를 형성한 후 차폐막을 이식한 군을 실험군으로, 아무 것도 넣지 않은 군을 대조군으로 하여 4주 경과 후 실험동물을 희생시킨 후 조직학적관찰을 시행하였다.

시간경과에 따른 부착세포수 관찰결과, 배양 14 일까지 조골세포의 수가 지속적으로 증가하였고, 주사전자현 미경으로 세포의 형태 관찰결과, 배양된 세포들은 중층의 형태로 성장하면서 시간경과에 따라 세포가 응집되는 양상을 나타내었다. 관찰 기간동안 $\mathrm{COL}, \mathrm{OP}$, 및 $\mathrm{OC} \mathrm{mRNA}$ 의 발현이 관찰되어 배양 전 기간동안 조골세포 의 형질이 잘 유지되고 있음을 알 수 있었다. 백서 두개골 결손부에 이식된 차폐막은 염증반응 없이 주위 조직 과 우수한 생체적합성을 나타내었으며, 차폐막을 이식하지 하지 않은 대조군에 비해 높은 신생골 형성을 나타 내었다.

이상의 관찰결과로 새로이 제작된 chitosan-PLLA 차폐막은 우수한 생체적합성 및 골재생능을 나타냄을 알 수 있었으며, 향후 이를 골조직 재생 및 치주조직유도재생 분야에 응용될 수 있을 것으로 생각된다.

주요어 : chitosan-PLLA 다공성 차폐막, 생체적합성, 재생 